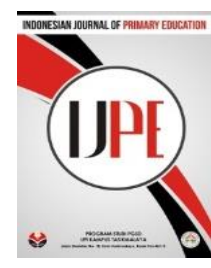

Vol. 3, No. 1 (2019) 62-69 ISSN: 2597-4866 Indonesian Journal of Primary Education

\title{
Implementasi Media Flashcard dalam Keterampilan Menulis Kata Baku
}

\author{
Rita $^{1}$, Dian Indihadi ${ }^{2}$ \\ Universitas Pendidikan Indonesia Kampus Tasikmalaya \\ *Corresponding author: ritaputri31@gmail.com ${ }^{1}$, dianindihadi@upi.edu ${ }^{2}$ \\ Diterima 24 April; 2019; Direview 10 Mei 2019; Diterima 28 Mei 2019 \\ Diterbitkan online 25 Juni 2019
}

\begin{abstract}
This research is focused on knowing media implementation flashcard in standard word writing skills. This study in the background behind the standard word writing skills of students who are still low, students have difficulty in writing standard words in accordance with the rules of language namely Indonesian spelling guidelines and students have difficulty distinguishing letters $f, p$, and $v$ in writing standard words. To overcome these difficulties researchers, provide an alternative by implementing media flashcard in Indonesian learning about writing standard words, because media flashcard can make it easier for students to imitate and remember the words contained in the cards. The purpose of this study is to describe the implementation of media flashcard in improving standard word writing skills in class III elementary school. The population and sample used were third grade students of Pasirkanyere State Elementary School, totaling 20 people. This research method uses pre-experimental design with pre-test and post-test design. The main instrument used by researchers is a written test writing a standard word in the form of matching and short answers. Data analysis was carried out by quantitative analysis using Microsoft Excel 2016, ANATES, and SPSS 23. Research findings showed that the results of writing standard words after implementing media flashcard were better than learning not to implement media flashcard, seen from the average acquisition pre-test amounting to 55.45 while the average post-test acquisition was 87.15. This shows that there is an increase in writing standard words through media flashcard. The results of the mean different test are 25.27. Based on the results of testing the data through SPSS, the results show that the significance is $<0.05$ (0.000<0.05), and the value of $M d>0(25.27>0)$, it can be seen that $H_{o}$ is rejected and $H_{a}$ is accepted. So it can be concluded that there is a difference in the average pretest scores and posttest. Thus the value posttest is higher than the value pretest. This shows that there is an increase in students' skills in writing standard words in Indonesian learning through the implementation of media flashcard in Indonesian language learning
\end{abstract}

Keywords: Writing Skills, Media Flashcard, Standard Words.

Abstrak

Penelitian ini difokuskan untuk mengetahui implementasi media flashcard dalam keterampilan menulis kata baku. Penelitian ini di latar belakangi oleh keterampilan menulis kata baku siswa yang masih rendah, siswa kesulitan dalam menulis kata baku sesuai dengan kaidah kebahasaan yakni pedoman ejaan bahasa Indonesia dan siswa sulit membedakan huruf $\mathrm{f}, \mathrm{p}$, dan $\mathrm{v}$ dalam menulis kata baku. Untuk mengatasi kesulitan tersebut peneliti memberikan salah satu alternatif dengan mengimplementasikan media flashcard dalam pembelajaran bahasa Indonesia perihal menulis kata baku, karena media flashcard dapat mempermudah siswa untuk meniru dan mengingat kata-kata yang terdapat dalam kartu-kartu tersebut. Tujuan penelitian ini yaitu mendeskripsikan pengimplementasian media flashcard dalam peningkatan keterampilan menulis kata baku di kelas III SD. Populasi dan sampel yang digunakan adalah siswa kelas III SD Negeri Pasirkanyere yang berjumlah 20 orang. Metode penelitian ini menggunakan pre-experimental design dengan desain pre-test and post-test design. Instrumen utama yang digunakan peneliti adalah tes tertulis menulis kata baku berupa menjodohkan dan jawaban singkat. Analisis data yang dilakukan adalah analisis kuantitatif dengan menggunakan Microsoft Excel 2016, ANATES, dan SPSS 23. Temuan penelitian menunjukkan bahwa hasil menulis kata baku sesudah mengimplementasikan media flashcard lebih baik dari pada pembelajaran tidak mengimplementasikan media flashcard, dilihat dari perolehan rata-rata pre-test sebesar 55,45 sedangkan perolehan rata-rata post-test sebesar 87,15. Hal tersebut menunjukkan bahwa terdapat peningkatan menulis kata baku melalui media flashcard. Hasil uji rata-rata beda (mean different) sebesar 25,27. Berdasarkan hasil pengujian data melalui SPSS diperoleh hasil bahwa signifikasi $<0,05(0,000<0,05)$, dan nilai $\mathrm{Md}>0(25,27>0)$, maka dapat diketahui bahwa $\mathrm{H}_{\mathrm{o}}$ ditolak dan $\mathrm{H}_{\mathrm{a}}$ diterima. Jadi dapat disimpulkan ada perbedaan rata-rata skor pretest dan posttest. Dengan demikian nilai posttest lebih tinggi dari nilai pretest. Hal tersebut menunjukkan bahwa terdapat peningkatan keterampilan siswa menulis kata baku pada pembelajaran bahasa Indonesia melalui implementasi media flashcard pada pembelajaran bahasa Indonesia.

Kata Kunci: Keterampilan Menulis, Media Flashcard, Kata Baku. 



\section{PENDAHULUAN}

Mata pelajaran bahasa Indonesia memiliki empat aspek keterampilan berbahasa. Keterampilan berbahasa tersebut yakni membaca, berbicara, mendengarkan dan menulis. Menulis termasuk salah satu dari empat keterampilan berbahasa yang penting yang harus dikuasai siswa. Hal tersebut sesuai dengan pernyataan Javed, Juan, dan Nazli (dalam Ayudia, Suryanto, \& Waluyo, 2016, hlm. 35) bahwa "kemampuan menulis lebih sulit dibandingkan dengan kemampuan berbahasa lainnya”. Maka dari itu pembelajaran bahasa Indonesia mulai diajarkan sejak kita duduk di bangku sekolah dasar karena diharapkan siswa mampu menguasai, memahami, dan mengimplementasikan keterampilan berbahasa dengan baik dan benar.

Di sekolah dasar menulis terbagi kedalam bentuk pembelajaran, salah satunya adalah menulis kata baku. . Kata baku merupakan kata-kata yang sesuai dengan kaidah kebahasaan. Salah satu kaidah tersebut adalah penggunaan ejaan. Suwarna (2012, hlm. 41) mengemukakan bahwa ejaan adalah suatu kaidah cara menggambarkan bunyi-bunyi seperti kata, kalimat dan lain sebagainya dalam bentuk tulisan (huruf-huruf) serta menggunakan tanda-tanda bacaan".

Kemampuan siswa dalam berbahasa Indonesia salah satunya dapat diukur dari keterampilan menuliskan kata baku yang dimiliki siswa. Semakin banyak kata baku yang dapat ditulis, semakin baik keterampilan siswa dalam berbahasa Indonesia. Karena pada hakikatnya tujuan pembelajaran bahasa Indonesia di sekolah dasar adalah siswa mampu menggunakan Bahasa Indonesia dengan baik dan benar.

Pembelajaran bahasa Indonesia dapat dioptimalkan apabila media pembelajaran yang digunakan guru sesuai dengan tujuan pembelajaran. Guru dituntut untuk dapat mengembangkan keterampilan membuat media pembelajaran yang akan digunakan apabila media tersebut belum tersedia. Hernawan, dkk. (2007, hlm.4) mengemukakan bahwa " media pembelajaran pada hakikatnya jembatan dari pesan-pesan atau bahan ajar (messages) yang disampaikan oleh guru agar pesan-pesan atau bahan ajar yang diterima siswa diserap dengan cepat dan tepat sesuai dengan tujuannya".

Selama ini yang menjadi penyebab siswa mengalami kesulitan dalam menulis kata baku dikarenakan siswa mengalami kesulitan untuk menulis kata baku yang sesuai dengan kaidah kebahasaan (ejaan), siswa sulit membedakan huruf $f, v$, dan $p$, serta siswa terbiasa menggunakan bahasa pertama yang menyebabkan penulisan kata baku tidak sesuai dengan kaidah kebahasaan. Hambatan lain yaitu siswa kurang termotivasi dalam pembelajaran menulis kata baku. Oleh sebab itu siswa memerlukan rangsangan atau stimulus yang diberikan guru sehingga dapat 
memberikan daya tarik dan memudahkan siswa dalam menulis kata baku.

Salah satu cara bisa dilakukan guru yaitu memberikan rangsangan atau stimulus dalam pembelajaran sastra. Stimulus itu bisa berupa media pembelajaran, salah satunya berupa media flashcard.

Flashcard digunakan sebagai media pembelajaran bahasa dan berguna untuk menyampaikan materi berupa pengenalan huruf baru, kata, dan lain-lain. Sebagaimana dikemukakan oleh Khodareza (2012, hlm. 137) bahwa "flashcard useful for training and learning, syllables, words, and other information". Artinya flashcard berguna untuk melatih atau belajar suku kata, kata dan informasi lainnya. Sejalan dengan pendapat tersebut Suyanto (2008, hlm. 47) mengemukakan bahwa "anak-anak akan lebih cepat belajar kata-kata atau kosakata bila ditunjang dengan alat peraga, misalnya gambar atau benda nyata". Dari pendapat tersebut dapat disimpulkan bahwa pengajaran kata baku bagi kelas rendah harus menggunakan benda-benda nyata atau gambar yang depan memvisualkan benda tersebut seolah-olah terlihat seperti asli karena anak kelas rendah masih berada pada tahap operasional konkrit.

\section{METODE PENELITIAN}

Desain penelitian yang dilakukan peneliti adalah Pre-Experimental Design dengan bentuk One-Grup Pretest-Posttest Design. Bentuk desain ini digambarkan sebagai berikut:

\section{$\mathrm{O}_{1} \mathrm{X} \mathrm{O}_{2}$ \\ Gambar 1 \\ One-Grup Pretest-Posttest Design \\ (Sugiyono (2016, hlm.75)}

\section{Keterangan:}

$\mathrm{O}_{1} \quad=$ Pretest (sebelum diberikan

perlakuan/ treatment)

$\mathrm{X}=$ Perlakuan (Treatment)

$\mathrm{O}_{2} \quad=$ Posttest (setelah perlakuan/

\section{treatment)}

Sugiono (2016, hlm. 80) mengemukakan bahwa "Populasi adalah wilayah generalisasi yang terdiri atas objek atau subjek yang mempunyai kualitas dan karakteristik tertentu yang ditetapkan oleh peneliti untuk dipelajari kemudian ditarik kesimpulannya". Populasi dalam penelitian ini adalah siswa kelas III SDN Pasirkanyere yang berjumlah 20 orang, yaitu 9 orang laki-laki dan 11 orang perempuan. Dalam penelitian ini, teknik sampling yang digunakan untuk mengambil sampel yaitu teknik non probability sampling atau sampling jenuh karena jumlah siswanya kurang dari 30 orang. Sampling jenuh adalah teknik penentuan sampel bila semua anggota populasi digunakan sebagai sampel.

Instrumen pengumpulan data yang digunakan pada penelitian ini adalah tes. Tes sebagai instrumen pengumpulan data adalah suatu cara untuk mengadakan penilaian berupa serangkaian pertanyaan atau latihan yang akan digunakan untuk mengukur keterampilan pengetahuan, kemampuan atau bakat yang dimiliki individu atau kelompok. Instrumen yang digunakan adalah tes tertulis 
dengan 20 item soal. 5 soal berupa menjodohkan dan 15 soal berupa jawaban singkat.

Tes tertulis ini digunakan untuk mengukur sejauh mana keterampilan menulis kata baku, baik sebelum diberi perlakuan maupun sesudah diberi perlakuan di dengan mengimplementasikan media flashcard. Instrumen penelitian pendukung yang digunakan dalam penelitian ini yaitu pengembangan Rencana Pelaksanaan Pembelajaran (RPP). RPP digunakan sebagai acuan atau pedoman bagi guru dalam melaksanakan kegiatan pembelajaran.

Tulisan kata baku ditandai oleh bentuk tulisan yang sesuai dengan ejaan penulisan kata baku. Penulisan kata baku memiliki kriteria penilaian yakni jika dituliskan di awal kalimat maka menggunakan huruf kapital, penulisan kata baku harus sesuai dengan keutuhan lambang tulisan kata baku, ketepatan pengorganisasian lambang kata baku, kerapian tulisan kata baku dan ketepatan lambang tulisan pada kata baku.

Berikut adalah tabel penskoran menulis kata baku.
Tabel 1

Penskoran Menulis Kata Baku.

\begin{tabular}{|c|c|c|c|}
\hline No & Aspek & Kriteria & Skor \\
\hline \multirow[t]{2}{*}{1} & \multirow{2}{*}{$\begin{array}{l}\text { Keutuhan lambang } \\
\text { tulisan kata baku }\end{array}$} & Tepat & 1 \\
\hline & & Tidak tepat & 0 \\
\hline \multirow[t]{2}{*}{2} & \multirow{2}{*}{$\begin{array}{l}\text { Ketepatan } \\
\text { pengorganisasian } \\
\text { lambang tulisan } \\
\text { kata baku }\end{array}$} & Tepat & 1 \\
\hline & & Tidak tepat & 0 \\
\hline \multirow[t]{2}{*}{3} & \multirow{2}{*}{$\begin{array}{l}\text { Ketepatan lambang } \\
\text { tulisan pada kata } \\
\text { baku }\end{array}$} & Tepat & 1 \\
\hline & & Tidak tepat & 0 \\
\hline \multirow[t]{2}{*}{4} & \multirow[t]{2}{*}{$\begin{array}{l}\text { Kerapian } \\
\text { kata baku }\end{array}$} & Tepat & 1 \\
\hline & & Tidak tepat & 0 \\
\hline \multirow[t]{2}{*}{5} & \multirow{2}{*}{$\begin{array}{l}\text { Ketepatan } \\
\text { penulisan } \\
\text { kapital }\end{array}$} & Tepat & 0 \\
\hline & & Tidak tepat & 1 \\
\hline
\end{tabular}

Berikut adalah analisis data yang digunakan, langkah pertama yang dilakukan adalah analisis deskriptif, kemudian uji prasyarat analisis yakni uji normalitas data untuk menguji apakah data berdistribusi normal atau tidak. Jika berdistribusi normal, maka statistik yang digunakan adalah statistik parametris. Setelah data dianalisis dan dinyatakan berdistribusi normal, maka langkah berikutnya adalah uji hipotesis menggunakan paired sampel t-test. Sedangkan jika data dinyatakan tidak berdistribusi normal, maka statistik yang digunakan adalah statistik nonparamtris dengan menggunakan uji wilcoxon.

\section{HASIL DAN PEMBAHASAN}

Penelitian ini telah di laksanakan tanggal 27- 11 Mei 2018 di SD Negeri Pasirkanyere. Selanjutnya peneliti pada proses pengolahan 
data adalah menggunakan interval kategori menurut (Rahmat \& Solehudin, 2006, hal. 65) yaitu sebagai berikut:

\section{Tabel 2}

\section{Interval Kategori}

\begin{tabular}{lll}
\hline No & \multicolumn{1}{c}{ Interval } & \multicolumn{1}{c}{ Kategori } \\
\hline 1 & $\mathrm{X} \geq \bar{X}_{\text {ideal }}+1,5_{\text {idela }}$ & Sangat Tinggi \\
\hline 2 & $\bar{X}_{\text {ideal }}+0,5 \leq \mathrm{X}<\bar{X}_{\text {ideal }}+$ & Tinggi \\
& $1,5 \mathrm{~S}_{\text {ideal }}$ & \\
\hline 3 & $\bar{X}_{\text {ideal }}-0,5 \mathrm{~S}_{\text {ideal }} \leq \mathrm{X}<\bar{X}_{\text {ideal }}+$ & Sedang \\
& $0,5 \mathrm{~S}_{\text {ideal }}$ \\
\hline 4 & $\bar{X}_{\text {ideal }}-1,5 \mathrm{~S}_{\text {ideal }} \leq \mathrm{X}<\bar{X}_{\text {ideal }}-$ & Rendah \\
& $0,5 \mathrm{~S}_{\text {ideal }}$ & \\
\hline 5 & $\mathrm{X}<\bar{X}_{\text {ideal }}-1,5 \mathrm{~S}_{\text {ideal }}$ & Sangat Rendah \\
\hline
\end{tabular}

Dapat ditetapkan penskoran skor dengan Xideal sebesar $100, \bar{X}_{\text {ideal sebesar }}$ 50, dan Sideal sebesar 16,67 .

Setelah diperoleh data dari hasil pretest dan posttest didapatkan skor dan kategorinya. Data hasil pretest dan posttest sebagai berikut:

Tabel 3

Perbandingan keterampilan Menulis Kata Baku Pretest dan Posttest

\begin{tabular}{l|l|l|l|l|l}
\hline \multirow{2}{*}{ N } & \multirow{2}{*}{\begin{tabular}{l} 
Kategor \\
\cline { 3 - 6 }
\end{tabular}} & \multicolumn{3}{|l|}{ Pretes } & \multicolumn{2}{l}{ Posttes } \\
\cline { 3 - 6 } & Fensi & $\begin{array}{l}\text { Perse } \\
\text { ntase }\end{array}$ & $\begin{array}{l}\text { Frekue } \\
\text { nsi }\end{array}$ & $\begin{array}{l}\text { Presen } \\
\text { tase }\end{array}$ \\
\hline 1 & $\begin{array}{l}\text { Sangat } \\
\text { Tinggi }\end{array}$ & 0 & $0 \%$ & 18 & $90 \%$ \\
\hline 2 & Tinggi & 4 & $20 \%$ & 2 & $10 \%$ \\
\hline 4 & Sedang & 14 & $70 \%$ & 0 & $0 \%$ \\
\hline 5 & $\begin{array}{l}\text { Sangat } \\
\text { Rendah }\end{array}$ & 2 & $10 \%$ & 0 & $0 \%$ \\
\hline
\end{tabular}

Dari data tersebut dapat disimpulkan bahwa keterampilan siswa dalam menulis kata baku perihal alat-alat komunikasi setelah dilakukan pembelajaran menulis kata baku dengan mengimplementasikan media flashcard, siswa kelas III SDN Pasirkanyere pada saat dilakukan pretest kebanyakan hasil siswa berada pada kategori sedang, tidak ada siswa yang mendapatkan kategori sangat tinggi, siswa yang mendapatkan kategori tinggi 4, siswa yang mendapatkan kategori sedang 14 siswa, dan 2 orang mendapatkan kategori rendah. Sedangkan setelah dilakukan pembelajaran dengan mengimplementasikan media flashcard terjadi peningkatan yang signifikan yaitu siswa yang masuk kategori sangat tinggi awalnya 0\% menjadi $90 \%$, sedangkan siswa yang termasuk kategori tinggi yang awalnya 20\% menjadi $10 \%$, sedangkan siswa yang termasuk kategori sedang yang awalnya $70 \%$ menjadi $0 \%$ karena siswa kebanyakan masuk kategori sangat tinggi dan tinggi, siswa yang termasuk kategori rendah yang awalnya 10\% menjadi 0\% karena siswa kebanyakan masuk kategori sangat tinggi dan tinggi, dan tidak ada siswa yang termasuk kategori yang sangat rendah. Hal ini membuktikan bahwa pembelajaran dengan mengimplementasikan media flashcard dapat meningkatkan keterampilan menulis kata baku perihal alat-alat komunikasi di kelas III SDN Pasirkanyere.

Selanjutnya, untuk melihat pengimplementasian media flashcard dalam 
peningkatan keterampilan menulis kata baku, maka dilakukan perhitungan normal gain ( $\mathrm{N}$ Gain) terhadap perbedaan antara hasil sebelum diberikan perlakuan (pretest) dengan hasil setelah diberikan perlakuan (posttest) yang diperoleh siswa kelas III SDN Pasirkanyere Kecamatan Cibalong Kabupaten Tasikmalaya. Uji N-Gain merupakan hasil bagi dari selisih skor pretest dengan skor posttest dan selisih dari skor ideal dengan skor pretest. Data hasil pengujian N-Gain sebagai berikut:

Tabel 4

Uji N-Gain Pretest dan Posttest

\begin{tabular}{|c|c|c|c|c|c|}
\hline \multirow[b]{2}{*}{$\begin{array}{c}\text { Responde } \\
\mathbf{n}\end{array}$} & \multicolumn{4}{|c|}{ Uji N-Gain } & \multirow{2}{*}{$\begin{array}{c}\text { Kategori } \\
\text { peningkata } \\
\text { n }\end{array}$} \\
\hline & $\begin{array}{c}\text { Pre- } \\
\text { test }\end{array}$ & $\begin{array}{l}\text { Post } \\
\text {-test }\end{array}$ & $\begin{array}{c}\text { Gai } \\
\boldsymbol{n} \\
\text { (d) }\end{array}$ & $\begin{array}{l}N- \\
\text { gain }\end{array}$ & \\
\hline $\mathrm{S} 1$ & 47 & 79 & 32 & 0.60 & $\begin{array}{l}\text { Cukup } \\
\text { Efektif }\end{array}$ \\
\hline $\mathrm{S} 2$ & 64 & 90 & 26 & 0.72 & $\begin{array}{l}\text { Cukup } \\
\text { Efektif }\end{array}$ \\
\hline S3 & 56 & 82 & 26 & 0.59 & $\begin{array}{l}\text { Cukup } \\
\text { Efektif }\end{array}$ \\
\hline S4 & 57 & 87 & 30 & 0.70 & $\begin{array}{l}\text { Cukup } \\
\text { Efektif }\end{array}$ \\
\hline S5 & 56 & 90 & 34 & 0.77 & Efektif \\
\hline S6 & 58 & 86 & 28 & 0.66 & $\begin{array}{l}\text { Cukup } \\
\text { Efektif }\end{array}$ \\
\hline S7 & 57 & 92 & 35 & 0.81 & Efektif \\
\hline S8 & 56 & 88 & 32 & 0.72 & $\begin{array}{l}\text { Cukup } \\
\text { Efektif }\end{array}$ \\
\hline S9 & 57 & 93 & 36 & 0.83 & Efektif \\
\hline S10 & 67 & 89 & 22 & 0.66 & $\begin{array}{l}\text { Cukup } \\
\text { Efektif }\end{array}$ \\
\hline S11 & 54 & 90 & 36 & 0.78 & Efektif \\
\hline $\mathrm{S} 12$ & 39 & 77 & 38 & 0.62 & $\begin{array}{l}\text { Cukup } \\
\text { Efektif }\end{array}$ \\
\hline
\end{tabular}

\begin{tabular}{|c|c|c|c|c|c|}
\hline S13 & 65 & 90 & 25 & 0.71 & $\begin{array}{l}\text { Cukup } \\
\text { Efektif }\end{array}$ \\
\hline S14 & 58 & 87 & 29 & 0.69 & $\begin{array}{l}\text { Cukup } \\
\text { Efektif }\end{array}$ \\
\hline S15 & 55 & 90 & 35 & 0.77 & Efektif \\
\hline S16 & 48 & 91 & 43 & 0.82 & Efektif \\
\hline S17 & 73 & 100 & 27 & 1 & Efektif \\
\hline S18 & 58 & 94 & 36 & 0.85 & Efektif \\
\hline S19 & 48 & 73 & 25 & 0.48 & $\begin{array}{l}\text { Kurang } \\
\text { Efektif }\end{array}$ \\
\hline S20 & 36 & 75 & 39 & 0.60 & $\begin{array}{l}\text { Cukup } \\
\text { Efektif }\end{array}$ \\
\hline Jumlah & $\mathbf{1 1 0 9}$ & $\mathbf{1 7 4 3}$ & $\mathbf{6 3 4}$ & $\begin{array}{c}\mathbf{1 4 , 4} \\
\mathbf{6}\end{array}$ & $\begin{array}{c}\text { Cukup } \\
\text { Efektif }\end{array}$ \\
\hline Rata-rata & $\begin{array}{c}\mathbf{5 5 , 4} \\
\mathbf{5}\end{array}$ & $\mathbf{8 7 , 1}$ & $\mathbf{5 1 , 7}$ & $\mathbf{0 , 7 2}$ & \\
\cline { 1 - 4 } & & & &
\end{tabular}

Berdasarkan hasil perhitungan $\mathrm{N}$-gain diketahui bahwa rata-rata hasil pretest seluruh siswa kelas III yang berjumlah 20 orang adalah 55,45 sedangkan rata-rata hasil posttes adalah 87,15, dengan nilai $N$-gain yang berkategorikan cukup efektif, yaitu 0,72. Hasil perhitungan pretest dan posttest menunjukkan adanya peningkatan terhadap hasil siswa dalam pembelajaran keterampilan menulis kata baku. Dengan demikian pengimplementasian media flashcard terhadap kemampuan siswa dalam menulis kata baku.

Untuk mengetahui normal tidaknya data, maka pada penelitian ini uji normalitas data dilakukan dengan melihat signifikansi pada Shapiro Wilk. "Dengan kriteria pengujian jika signifikansi > 0,05, maka data berdistribusi 
normal. Sebaliknya jika signifikansi $<0,05$, maka data tidak terdistribusi secara normal.

Pada penelitian ini nilai Shapiro Wilk pada signifikansi datanya, diperoleh dari hasil pengolahan data menggunakan program SPSS 23. Berdasarkan hasil uji normalitas, diketahui bahwa data pre-test dengan signifikansi 0,228 dan data post-test dengan signifikansi 0,98. Karena nilai signifikansi < 0,05 maka dapat disimpulkan bahwa data sampel pre-test dan post-test siswa berdistribusi normal.

Karena data yang diperoleh berdistribusi normal, maka langkah selanjutnya adalah melakukan uji hipotesis parametrik. Dalam uji hipotesis ini, peneliti menggunakan uji Paired Sample Test melalui program SPSS 23.

Setelah melakukan uji $\mathrm{t}$ (paired sample $\mathrm{t}$ test) maka selanjutnya adalah pengujian hipotesis sebagai berikut:

1) Merumuskan hipotesis

Ho: "Keterampilan menulis kata baku tidak menunjukkan peningkatan apabila pembelajaran mengimplementasikan media flashcard."

Ha: "Keterampilan menulis kata baku menunjukkan peningkatan apabila pembelajaran mengimplementasikan media flashcard."

2) Menentukan tingkat signifikansi

Taraf ini menggunakan taraf signifikansi $5 \% \quad(\alpha=0,05)$. Tingkat signifikansi dalam hal ii berarti kmenggambil resiko salah dalam mengambil keputusan untuk menolak hipotesis yang benar sebanyakbanyaknya $5 \%$ (signifikansi $5 \%$ atau 0,05 adalah ukuran standar yang sering digunakan dalam penelitian).

3) Menentukan t-test

Untuk mengetahui t hitung dapat diperoleh dengan cara uji paired sample t-test menggunakan SPSS.23. Sedangkan untuk mengetahui uji rata-rata beda dapat menggunakan perhitungan Mean different dengan rumus sebagai berikut:

$$
\mathrm{t}=\frac{M d}{\sqrt{\frac{\sum X^{2} d}{N(N-1)}}} \quad M d=\frac{\sum d}{N}
$$

Dari output SPSS, diketahui nilai t hitung adalah 25,265 dan signifikasi 0,000. Sedangkan untuk mengetahui uji rata-rata beda dapat menggunakan perhitungan Mean different dengan rumus sebagai berikut:

$$
\begin{aligned}
& \mathrm{t}=\frac{M d}{\sqrt{\frac{\sum X^{2} d}{N(N-1)}}} \\
& \mathrm{t}=\frac{31,7}{\sqrt{\frac{598.2}{20(19)}}}=\frac{31,7}{\sqrt{1,574}}=\frac{31,7}{1,254}=25,27
\end{aligned}
$$

4) Membuat kesimpulan

Berdasarkan hasil pengujian data melalui SPSS diperoleh hasil bahwa signifikasi < $0,05(0,000<0,05)$, dan nilai $\mathrm{Md}>0$ $(25,27>0)$, maka dapat diketahui bahwa $\mathrm{H}_{\mathrm{o}}$ ditolak dan $\mathrm{H}_{\mathrm{a}}$ diterima. Jadi dapat disimpulkan ada perbedaan rata-rata skor pretest dan posttest. Dari perhitungan di atas dapat diketahui bahwa nilai posttest lebih tinggi dari nilai pretest. Jadi pembelajaran mengimplementasikan media 
flashcard memberikan peningkatan yang signifikan pada keterampilan menulis kata baku di kelas III SD.

\section{SIMPULAN}

Berdasarkan penelitian tentang implementasi media flashcard dalam keterampilan menulis kata baku siswa pada pembelajaran bahasa Indonesia di kelas III SDN Pasirkanyere Kecamatan Cibalong Kabupaten Tasikmalaya, maka dapat disimpulkan sebagai berikut :

1. Berdasarkan data hasil pre-test mengenai keterampilan menulis kata baku siswa kelas III pada pembelajaran bahasa Indonesia sebelum mengimplementasikan media flashcard diperoleh jumlah skor 1109 dengan rata-rata 55,45. Perolehan skor terendah yaitu 36 dan skor tertinggi yaitu 73.

2. Berdasarkan data hasil post-test mengenai keterampilan menulis kata baku siswa kelas III pada pembelajaran bahasa Indonesia sesudah mengimplementasikan media flashcard diperoleh jumlah skor 1743 dengan rata-rata 87,15. Perolehan skor terendah yaitu 73 dan skor tertinggi yaitu 100 .

3. Peningkatan dapat dilihat berdasarkan hasil perhitungan N-Gain. Diperoleh rata-rata NGain yaitu 0,72 , yang menandakan bahwa peningkatan cukup efektif dan signifikan. Hal tersebut ditegaskan dengan hasil uji hipotesis dengan nilai asymp sig sebesar 0,00 . Karena nilai asymp sig sebesar $0,00<$
0,05 maka Ha diterima dan Ho ditolak. Dengan demikian dapat disimpulkan bahwa terdapat peningkatan keterampilan menuliskan kata baku pada pembelajaran bahasa Indonesia sesudah mengimplementasikan media flashcard.

\section{DAFTAR PUSTAKA}

Arikunto, S. (2010).Prosedur Penelitian Pendekatan Praktek. Jakarta: Penerbit Rineka Cipta.

Ayudia, Suryanto, E., \& Waluyo, B. (2016). Analisis Kesalahan Penggunaan Bahasa Indonesia Dalam Laporan Hasil Observasi Pada Siswa Smp. Basastra Jurnal Penelitian Bahasa, Sastra Indonesia dan Pengajarannya Volume 4 , 34-49.

Hernawan, A. H. dkk.(2007). Media Pembelajaran.Bandung: UPI PRESS.

Khodareza, M. (2012). The Effect of Using Vocabulary Flash Card on Iranian PreUniversity Studentse ${ }^{\text {ee }}$ Vocabulary Knowledge. International Education Studies Vol. 5, No. 3, 134-147.

Rakhmat, C. dkk.(2006). Pengukuran dan Penilaian Hasil Belajar.Bandung: CV ANDIRA.

Sugiyono (2016). Metode Penelitian Kuantitatif, Kualitatif, dan R\&D. Bandung: Alfabeta.

Suwarna, D. (20120). Cerdas Berbahasa Indonesia Berbahasa Dengan Pemahaman dan Pendalaman. Ciputat: Jelajah Nusa.

Suyanto, K. E. (2008). English For Young Learners. Jakarta: Bumi Aksara 